\title{
OSTEOTOMY OF THE CALCANEUS AND CONCOMITANT PLANTAR STRIPPING IN CHILDREN WITH TALIPES CAVO-VARUS
}

\author{
S. Dekel and S. L. Weissman, Tel-Aviv, Israel \\ From the Department of Orthopaedics and Traumatology, Municipal Government Medical Centre, Ichilov Hospital, \\ Tel-Aviv University Medical School and Faculty for Continuing Medical Education
}

Cavo-varus deformity of the foot secondary to poliomyelitis, congenital club foot or other diseases is a rather complex deformity caused by imbalance of intrinsic and extrinsic muscles of the foot. Correction by tarsal reconstruction with or without soft-tissue procedures is the accepted form of treatment. However, in children too young for tarsal reconstruction the problem remains, because the deformity is progressive and structural changes in tarsal bones will occur despite conservative measures.

Dwyer in 1955 presented a new approach. He advised correction of the varus deformity of the heel by removing a wedge of bone from the outer aspect of the calcaneus combined with subcutaneous division of the contracted plantar fascia. In this way the foot became plantigrade, and therefore weight-bearing exerted a corrective influence which resulted in progressive improvement of the deformity. In his opinion the operation was mainly a prophylactic one and should be performed before there was gross structural deformity and while active growth was still taking place. He reported sixty-three operations in forty-seven children and observed striking improvement in the deformity as well as in the gait of the children and the way their shoes were worn.

Fisher and Shaffer (1970) reported a new method of evaluation used in sixty-three calcaneal osteotomies. They assessed their results according to the improvement achieved separately in heel varus, cavus and forefoot adduction. Their results showed that calcaneal osteotomy was generally effective in correcting heel varus particularly in patients with club feet who required bony operation for correction but were too young for triple arthrodesis. They found the operation ineffective for correcting cavus and forefoot adduction.

The present investigation was undertaken in order to assess the prophylactic value of this operation in a series of children most of whom were operated upon at an early age and followed for many years. The purpose was to ascertain whether the results achieved in young children remained unaffected by years of rapid growth, and whether tarsal reconstruction was needed by the end of that period.

\section{CLINICAL MATERIAL}

During the years 1960 to 1970 , thirty-eight osteotomies of the calcaneus with concomitant plantar stripping were performed in thirty-three children (sixteen girls and seventeen boys). Operation-The operation consisted in removing a wedge of bone 6-12 millimetres wide at its base from the lateral aspect of the calcaneus, posterior to the peroneal tendons. The space was closed manually by everting and dorsiflexing the foot. Concomitantly the origin of short plantar muscles was stripped by the method of Steindler (1940) through a separate incision on the inner aspect of the heel.

A plaster was applied after operation and the children were kept in bed for six weeks. A walking plaster was then applied for another six weeks, after which the child was left free and allowed to wear ordinary shoes.

Etiology-The causes of deformity were poliomyelitis (twenty children, twenty-two feet), congenital (ten children, twelve feet), cerebral palsy (one child, two feet) and fracture or soft-tissue injury (two children, two feet) (Table l). 
The average age at operation was seven and a half years but varied from four to fifteen years. Most of the children were operated on at between six and nine years of age (Table II).

All the patients were re-examined at regular intervals for the purpose of this study at times ranging from two years to ten years after operation, the average being seventy months. By that time most (twenty-six patients) were over eleven years old. In all there was marked improvement during the first year after operation. However, with continued growth, the deformity recurred to a variable degree in some patients.

\section{RESULTS}

The results were assessed with regard to the need for tarsal reconstruction, taking into account the age at the follow-up examination. Furthermore, an attempt was made to assess this need in relation to the degree of correction achieved in each of the three elements of the deformity. Finally, the relation between the correction of these elements and the age at operation was considered.

The need for tarsal reconstruction (Table III)-Tarsal reconstruction by triple arthrodesis was performed or planned when the deformity recurred and the foot ceased to be plantigrade

TABLE I

Etiology of THE FoOt Deformity

\begin{tabular}{|l|c|c|}
\hline Cause of deformity & $\begin{array}{c}\text { Number of } \\
\text { patients }\end{array}$ & $\begin{array}{c}\text { Number of } \\
\text { feet }\end{array}$ \\
\hline Poliomyelitis & 20 & 22 \\
Congenital club foot & 10 & 12 \\
$\left.\begin{array}{l}\text { Cerebral palsy } \\
\text { Fracture } \\
\text { Soft-tissue injury }\end{array}\right\} \cdot$ & 3 & 4 \\
\hline \multicolumn{1}{|c|}{ Total . } & 33 & 38 \\
\hline
\end{tabular}

TABLE II

Age at Operation

\begin{tabular}{|c|c|}
\hline $\begin{array}{c}\text { Age } \\
\text { (years) }\end{array}$ & $\begin{array}{c}\text { Number of } \\
\text { feet }\end{array}$ \\
\hline $4-6$ & 11 \\
$7-9$ & 21 \\
$10-13$ & 5 \\
Over 14 & 1 \\
\hline Total . & 38 \\
\hline
\end{tabular}

(Figs. 1 and 2). The youngest age at which triple arthrodesis was performed was eleven years. At the time of this study twenty-six children had reached that age. Six children had undergone triple arthrodesis and it was proposed in two others. In three, there was slight recurrence not warranting tarsal reconstruction. Therefore, fourteen patients (with eighteen feet) out of twenty-six (with thirty feet) achieved a lasting satisfactory result (Figs. 3 to 6).

The remaining seven patients (with eight feet) were too young for definitive assessment, though most of them had satisfactory results. Only eight of the sixteen children with deformity caused by poliomyelitis obtained satisfactory results. All the children with congenital club foot or deformity from other causes obtained lasting satisfactory results.

Degree of correction of each of the elements of the deformity-The method of Fisher and Shaffer (1970) was used in order to assess the degree of correction of each of the following deformities: heel varus, cavus and forefoot adduction. Each deformity was classified into four grades: severe, moderate, mild and none (Table IV). The grade of deformity was assessed before and after the operation. An improvement of two grades or more (severe to mild or moderate to none) was rated "good". Improvement of one grade was rated "fair", and no improvement, worsening or over-correction was rated "poor". The assessment was made by comparing pre-operative and post-operative notes, photographs and radiographs. Complete records were available for thirty feet. The remaining eight feet were not used in this evaluation. Correction of varus deformity of the heel (Table V)-Good improvement was achieved in

VOL. 55 B, NO. 4, NOVEMBER 1973 


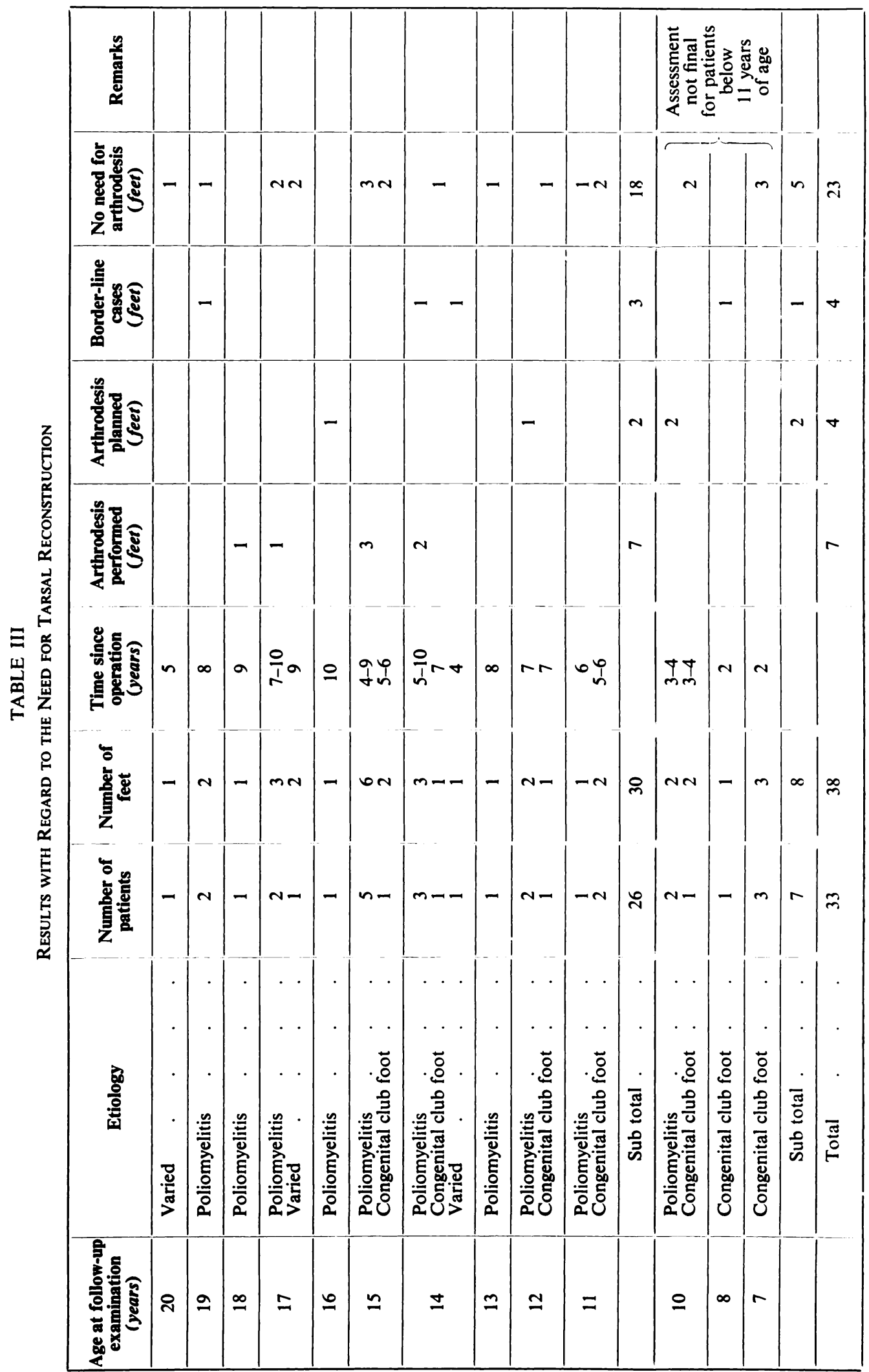

THE JOURNAL OF BONE AND JOINT SURGERY 


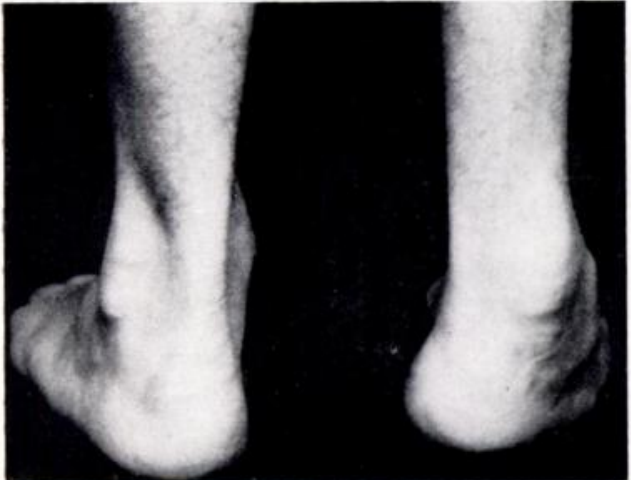

FIG. 1

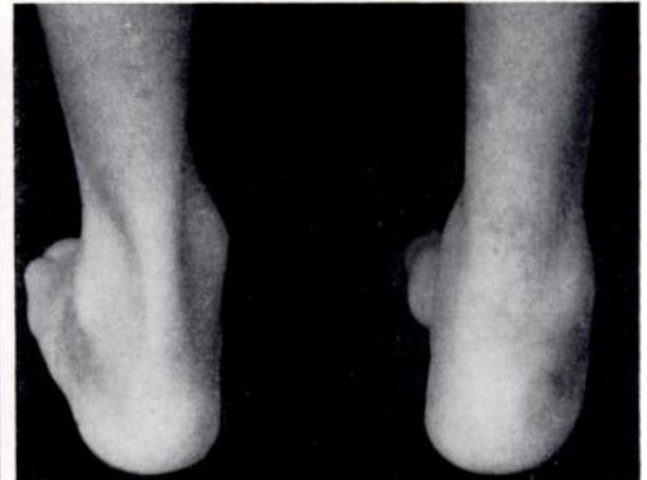

Fig. 2

Figure 1-Cavo-varus deformity of the right foot, following poliomyelitis, in a boy aged $8 \frac{1}{2}$ years. Figure 2-Aged 15: the deformity has recurred.

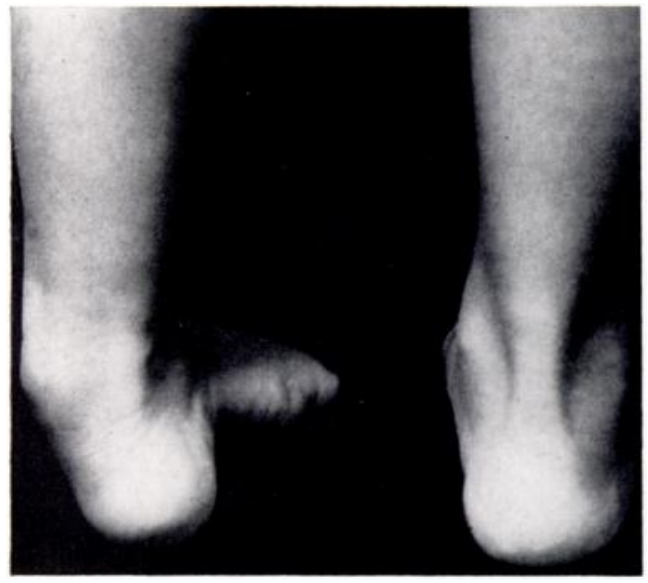

FIG. 3

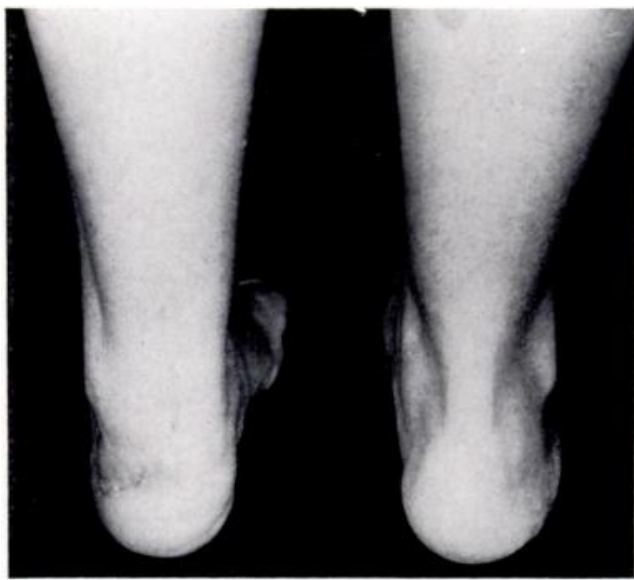

Fig. 4

Figure 3-Cavo-varus deformity of the left foot, following poliomyelitis, in a girl aged 7 years. Figure 4-Aged 15: the foot remains plantigrade.

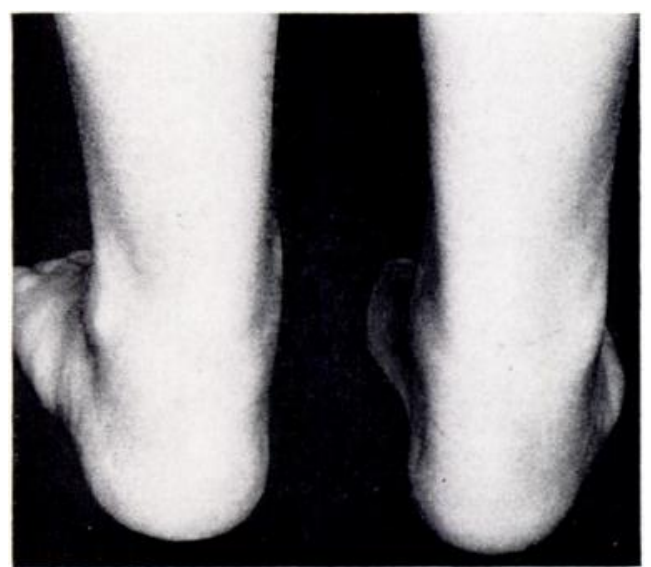

Fig. 5

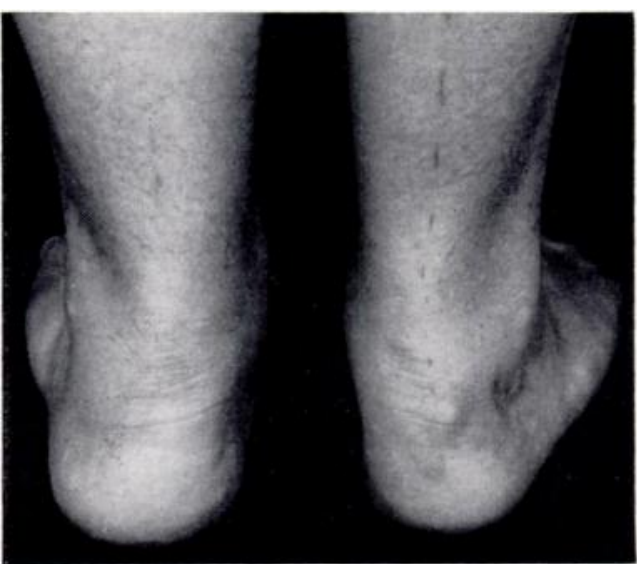

Fig. 6

Figure 5-Cavo-varus deformity of the right foot in a girl aged 7 years after closed treatment of congenital club foot. Figure 6-Aged 13: the foot remains plantigrade.

VOL. 55 B, NO. 4, NOVEMBER 1973 
twenty-three feet, fair improvement in three and no improvement in four. In children with club feet, good improvement was achieved in eleven out of twelve feet, whereas eight out of fourteen feet affected by the consequences of poliomyelitis showed good improvement.

The four poor results were in the patients who had had poliomyelitis. The only case of over-correction-with resulting valgus deformity-is included in this group.

All the seven feet assessed as fair or poor needed tarsal reconstruction. Only one out of twenty-three feet having a good improvement needed tarsal reconstruction. In this case, the initial 15 degrees varus was corrected to 4 degrees and, in accordance with the method, the improvement was graded as good. However, the foot was not plantigrade and therefore tarsal reconstruction had to be done.

TABLE IV

Grade of Severity (after Fisher and Shaffer)

\begin{tabular}{|c|c|c|c|}
\hline \multicolumn{4}{|c|}{ Degree of deformity } \\
\hline Grade & Varus & Cavus & Forefoot adduction \\
\hline None . & Valgus to neutral & Minimal or none & None \\
\hline Mild . & Up to 5 degrees & Mild & Up to 10 degrees \\
\hline Moderate & 6 to 10 degrees & Moderate & 11 to 20 degrees \\
\hline Severe. & Over 10 degrees & Severe & Over 20 degrees \\
\hline
\end{tabular}

TABLE V

Correction of Heel Varus (Thirty Feet)

\begin{tabular}{|c|c|c|c|c|}
\hline $\begin{array}{l}\text { Degree of } \\
\text { correction }\end{array}$ & $\begin{array}{c}\text { Number of } \\
\text { feet }\end{array}$ & Etiology & $\begin{array}{c}\text { Number of } \\
\text { feet }\end{array}$ & $\begin{array}{l}\text { Needed tarsal } \\
\text { reconstruction }\end{array}$ \\
\hline Good. & 23 & $\begin{array}{l}\text { Poliomyelitis } \\
\text { Congenital club foot } \\
\text { Varied. }\end{array}$ & $\begin{array}{r}8 \\
11 \\
4\end{array}$ & $\frac{1}{1}$ \\
\hline Fair . & 3 & $\begin{array}{l}\text { Poliomyelitis } \\
\text { Congenital club foot } \\
\text { Varied. }\end{array}$ & $\begin{array}{r}2 \\
1 \\
-\end{array}$ & $\begin{array}{l}2 \\
1 \\
-\end{array}$ \\
\hline Poor. & 4 & $\begin{array}{l}\text { Poliomyelitis } \\
\text { Congenital club foot } \\
\text { Varied. }\end{array}$ & $\underline{4}$ & $\underline{4}$ \\
\hline
\end{tabular}

Correction of cavus deformity (Table VI)-Good improvement was achieved in thirteen feet and fair improvement in eleven. No improvement was achieved in six feet. No difference in the results was found between congenital club feet and feet with deformity caused by poliomyelitis. Seven feet needed tarsal reconstruction, but heel varus was also present in every instance. Therefore, cavus alone was not a factor determining the need for such reconstruction.

Correction of adduction deformity of the forefoot (Table VII)-There was good correction in eight feet, partial correction in twelve and failure in ten. Children who had had poliomyelitis did rather better than those with congenital club feet. Six feet needed tarsal reconstruction, but heel varus was also present in every instance. Forefoot adduction alone was not a factor determining the need for tarsal reconstruction. 
Results in relation to age at operation (Table VIII)-The results did not vary much in relation to the age at operation. Nevertheless, correction of heel varus was achieved less often in children aged less than six years at the time of operation.

\section{DISCUSSION}

The prophylactic value of calcaneal osteotomy performed in a young child is proved if there is no need for any further operation when the child finishes growing. In our hands the operation was of decisive prophylactic value in only slightly more than half of the cases.

TABLE VI

Correction of Cavus (Thirty Feet)

\begin{tabular}{|c|c|c|c|c|c|}
\hline $\begin{array}{l}\text { Degree of } \\
\text { correction }\end{array}$ & $\begin{array}{c}\text { Number of } \\
\text { feet }\end{array}$ & Etiology & $\begin{array}{c}\text { Number of } \\
\text { feet }\end{array}$ & $\begin{array}{l}\text { Needed tarsal } \\
\text { reconstruction }\end{array}$ & $\begin{array}{l}\text { Border-line } \\
\text { cases }\end{array}$ \\
\hline Good. & 13 & $\begin{array}{l}\text { Poliomyelitis } \\
\text { Congenital club foot } \\
\text { Varied }\end{array}$ & $\begin{array}{l}8 \\
5 \\
2\end{array}$ & $\frac{2 *}{-}$ & $\begin{array}{l}- \\
-\end{array}$ \\
\hline Fair. & 11 & $\begin{array}{l}\text { Poliomyelitis } \\
\text { Congenital club foot } \\
\text { Varied }\end{array}$ & $\begin{array}{l}5 \\
5 \\
1\end{array}$ & $\begin{array}{l}2^{*} \\
1^{*}\end{array}$ & $\overline{-}$ \\
\hline Poor & 6 & $\begin{array}{l}\text { Poliomyelitis } \\
\text { Congenital club foot } \\
\text { Varied. }\end{array}$ & $\begin{array}{l}3 \\
2 \\
1\end{array}$ & $\frac{2 *}{-}$ & E \\
\hline
\end{tabular}

* Concerns patients who needed tarsal reconstruction also because of heel varus.

TABLE VII

Correction of Forefoot Adduction (Thirty FeEt)

\begin{tabular}{|l|c|c|c|c|c|c|}
\hline $\begin{array}{c}\text { Degree of } \\
\text { Correction }\end{array}$ & $\begin{array}{c}\text { Number of } \\
\text { feet }\end{array}$ & Etiology & $\begin{array}{c}\text { Number of } \\
\text { feet }\end{array}$ & $\begin{array}{c}\text { Needed tarsal } \\
\text { reconstruction }\end{array}$ & $\begin{array}{c}\text { Border-line } \\
\text { cases }\end{array}$ \\
\hline Good. & 8 & $\begin{array}{l}\text { Poliomyelitis } \\
\text { Congenital club foot } \\
\text { Varied . }\end{array}$ & 2 & 2 & - & - \\
Fair . & 12 & $\begin{array}{l}\text { Poliomyelitis } \\
\text { Congenital club foot } \\
\text { Varied . . }\end{array}$ & 7 & - & - \\
Poor. & 10 & $\begin{array}{l}\text { Poliomyelitis } \\
\text { Congenital club foot } \\
\text { Varied . . }\end{array}$ & 2 & - & - \\
\hline
\end{tabular}

* Concerns patients who needed tarsal reconstruction also because of heel varus.

Analysis of the results has shown that heel varus was the factor determining the need for tarsal reconstruction. Calcaneal osteotomy is, therefore, efficient only because it corrects the varus of the heel. This is in line with Dwyer's contention that heel varus is the major deforming force of the complex deformity and confirms the findings of Fisher and Shaffer (1970).

The fact that in slightly less than half of the cases the final correction was imperfect so that tarsal reconstruction was needed in just over one in four of the affected feet, may be explained either by incomplete correction at the time of the osteotomy or by actual recurrence of deformity. The latter may be suspected particularly in cases in which there was an obvious reason for muscular imbalance. In fact, almost all instances of need for tarsal reconstruction were in children suffering from the effects of infantile paralysis. 
The use of plantar stripping instead of plantar fasciotomy (as used by Dwyer) seemed justified by the assumption that the release of the contracted fascia and plantar muscles at their origin from the calcaneus may be more efficient than simple section of the fascia. It is our impression that such a release was helpful. However, the degree of its usefulness is difficult to ascertain.

TABLE VIII

Results with Relation to Age at Operation (Thirty Feet)

\begin{tabular}{|c|c|c|c|c|c|c|c|c|c|c|}
\hline \multirow{3}{*}{$\begin{array}{l}\text { Age group } \\
\text { (years) }\end{array}$} & \multirow{3}{*}{$\begin{array}{c}\text { Number of } \\
\text { feet }\end{array}$} & \multicolumn{9}{|c|}{ Result in relation to deformity } \\
\hline & & \multicolumn{3}{|c|}{ Varus } & \multicolumn{3}{|c|}{ Cavus } & \multicolumn{3}{|c|}{ Forefoot adduction } \\
\hline & & Good & Fair & Poor & Good & Fair & Poor & Good & Fair & Poor \\
\hline $4-6$ & 11 & 7 & 3 & 1 & 4 & 4 & 3 & 4 & 5 & 2 \\
\hline $7-9$ & 12 & 10 & - & 2 & 6 & 4 & 2 & 3 & 4 & 5 \\
\hline $10-13$ & 6 & 5 & - & 1 & 3 & 3 & - & 1 & 3 & 2 \\
\hline Over 14 & 1 & 1 & 一 & 一 & - & 一 & 1 & - & - & 1 \\
\hline Total & 30 & 23 & 3 & 4 & 13 & 11 & 6 & 8 & 12 & 10 \\
\hline
\end{tabular}

The fact that correction of heel varus was achieved more often in children over six years of age may be related to the greater size of the calcaneus in these children. Removing the wedge from the calcaneus is easier and more accurate in a well developed bone.

We feel that the operation is advisable in a young child. If successful, it will free him from the necessity of undergoing triple arthrodesis, with all the advantages inherent in the preservation of midtarsal-subtalar movement. If not successful it will have slowed the progression of the deformity and thus will have prepared the foot for an easier correction by the end of the growth period.

\section{SUMMARY}

1. Thirty-three children with thirty-eight feet affected by a cavo-varus deformity and treated by calcaneal osteotomy with concomitant stripping of plantar muscles were reviewed two to ten years after operation.

2. Out of twenty-six patients who were over eleven years old at the time of the review, fourteen (with eighteen feet) did not need any further treatment. In three other patients the deformity had recurred to a slight degree but did not warrant tarsal reconstruction. In the remaining nine patients the recurrence was marked and necessitated tarsal reconstruction.

3. The combined procedure is of value when there is progressive deformity in children too young for tarsal reconstruction.

\section{REFERENCES}

DWYer, F. C. (1959): Osteotomy of the Calcaneum for Pes Cavus. Journal of Bone and Joint Surgery, 41-B, 80. Fisher, R. L., and Shaffer, S. R. (1970): An Evaluation of Calcaneal Osteotomy in Congenital Clubfoot and Other Disorders. Clinical Orthopaedics and Related Research, 70, 141.

Sternder, A. (1940): Orthopaedic Operations: Indications, Technique and End Results, p. 100. Springfield, Illinois: Charles $\mathrm{C}$. Thomas. 